\title{
Correction to: The Coding and Small Non-coding Hippocampal Synaptic RNAome
}

\author{
Robert Epple $^{1} \cdot$ Dennis Krüger ${ }^{1,2} \cdot$ Tea Berulava $^{1} \cdot$ Gerrit Brehm $^{3,4} \cdot$ Momchil Ninov $^{5} \cdot$ Rezaul Islam $^{1} \cdot$ Sarah Köster $^{3,4}$. \\ Andre Fischer ${ }^{1,4,6}$
}

(C) The Author(s) 2022

\section{Correction to: Molecular Neurobiology https://doi.org/10.1007/s12035-021-02296-y}

The original version of this article unfortunately contained some mistakes.

There are changes in the authorship order and the list of authors. Dr. Momchil Ninov is added as the fifth author.

Open Access This article is licensed under a Creative Commons Attribution 4.0 International License, which permits use, sharing, adaptation, distribution and reproduction in any medium or format, as long as you give appropriate credit to the original author(s) and the source, provide a link to the Creative Commons licence, and indicate if changes were made. The images or other third party material in this article are included in the article's Creative Commons licence, unless indicated otherwise in a credit line to the material. If material is not included in the article's Creative Commons licence and your intended use is not permitted by statutory regulation or exceeds the permitted use, you will need to obtain permission directly from the copyright holder. To view a copy of this licence, visit http://creativecommons.org/licenses/by/4.0/.

Publisher's Note Springer Nature remains neutral with regard to jurisdictional claims in published maps and institutional affiliations.

The online version of the original article can be found at https://doi.org/ 10.1007/s12035-021-02296-y

Andre Fischer

andre.fischer@dzne.de

1 Department of Systems Medicine and Epigenetics, German Center for Neurodegenerative Diseases (DZNE), Von Siebold Str. 3a, 37075 Goettingen, Germany

2 Bioinformatics Unit, German Center for Neurodegenerative Diseases (DZNE), Von Siebold Str. 3a, 37075 Goettingen, Germany

3 Institute for X-Ray Physics, University of Goettingen, Goettingen, Germany

4 Cluster of Excellence "Multiscale Bioimaging: from Molecular Machines to Networks of Excitable Cells" (MBExC), University of Goettingen, Goettingen, Germany

5 Department of Neurobiology, Max-Planck Institute for Biophysical Chemistry, 37077 Göttingen, Germany

6 Department of Psychiatry and Psychotherapy, University Medical Center Goettingen, Goettingen, Germany 